\title{
O DILEMA DE ENSINAR O INTANGÍVEL
}

\author{
Rodrigo Queiroz
}

Os dois primeiros artigos desta edição abordam distintamente o ensino. "O discurso profissional e o ensino na formação do arquiteto e urbanista em São Paulo: 1948-1962", de Taiana Car Vidotto e Ana Maria Reis Goes Monteiro, aproxima as transformações quase simultâneas da estrutura curricular da FAUUSP e da atribuição profissional do arquiteto e urbanista, que reverberariam, em certa medida, no ensino da arquitetura e no ofício da profissão em outras regiões do país. Sara Miriam Goldchmit, Maria Cecília Loschiavo dos Santos e Luciene Ribeiro dos Santos, autoras de "Odiléa Toscano: design visual, espaços públicos e ensino", traçam o perfil plural desta professora que dedicou 26 anos às disciplinas de Programação Visual da FAUUSP, além de possuir uma consistente obra nos campos da ilustração e da pintura mural.

Estes dois artigos fazem pensar sobre a intrincada relação entre ensino e aprendizagem de uma atividade identificada pelo seu caráter pessoal. No âmbito do ensino do projeto do edifício, dois dados são minimamente necessários a uma primeira abordagem do exercício: o lugar e a função, que possui sua versão detalhada naquilo que convencionou-se chamar de programa. Em uma associação mais imediata, poderíamos dizer que o binômio lugar/programa está para a arquitetura assim como o binômio gênero/tema está para a pintura ou mesmo para a escultura, se nos restringirmos, é claro, a sua vertente acadêmica, que ainda pressupõe o tema como significado necessário à sua interpretação e o gênero como índice de sua classificação.

Além da consciência acerca do lugar e da função que o edificio deverá desempenhar, o aprendizado de projeto considera o estudo e a incorporação de procedimentos projetuais muitas vezes traduzidos na forma de esquemas, uns mais conceituais, quase codificados, outros mais literais, como diagramas nos quais os espaços se organizam por setores funcionais. A espacialização do projeto a partir de ensaios ainda esquemáticos, na forma de desenhos ou aproximações tridimensionais, permite a compreensão da ideia como um conceito formal ou partido, no qual é possível assimilar as primeiras decisões do autor, como um ponto de partida de onde é possível seguir para as próximas etapas do projeto.

No ambiente universitário, o projeto resulta de um diálogo entre o autor e seus interlocutores. Cabe ao professor conduzir as relações entre a interpretação dos dados concretos, a utilização dos instrumentos de análise e a apresentação de soluções possíveis, decorrente da reflexão sobre, justamente, os dados e os instrumentos. 
É sabido que a imediata síntese entre os componentes do binômio função/lugar não é suficiente para a aferição da pertinência do projeto enquanto linguagem. A elaboração de um primeiro argumento formal resultante da estrita interpretação do programa e dos condicionantes inerentes ao lugar faz do projeto, muitas vezes, a mera combinação dos elementos necessários à sua própria justificativa.

Contudo, devemos considerar que o projeto é também a sutil e intangível transformação do partido em imagem. Se o partido apoia-se na lógica e a realidade para se justificar, a imagem, por sua vez, decorre de um processo criativo, muitas vezes empírico, por isso subjetivo. Nesse sentido, soa angustiante a insistente pedagogia baseada na contraditória tentativa de racionalização da subjetividade. Trata-se de um modelo de ensino condenado à condição de refém de uma linguagem cuja aparência pertence, queiramos ou não, ao campo da arte e não da razão. Por mais que a pedagogia moderna reprima a forma autoral, toda forma projetada traz consigo sua carga autoral, seja ela modelar, seja ela marcada por um gesto original.

O estatuto moderno, do qual involuntariamente fazemos parte em maior ou menor grau, ganha feição, ainda nos dias de hoje, a partir de manipulação de uma gramática formal já incorporada ao procedimento projetual e ao imaginário do estudante e de seu interlocutor, o professor, como uma forma que, por ser a imagem acabada das suas próprias convicções, se exime da necessidade de se justificar como linguagem, pois trata-se de uma forma disciplinar tão paradoxalmente "naturalizada"que parece prescindir de qualquer argumento que a justifique.

Diante do moderno não mais como ruptura, mas como tradição, o ensino de projeto parece ainda insistir na atribuição de um juízo de valor lógico a um processo de pensamento ilógico e, porque não, irracional. Mais complexo que conferir uma estrutura pedagógica à aprendizagem sobre um trabalho sensível é atribuir um valor ao resultado desse trabalho. Refiro-me à avaliação. É comum que o controle sobre esse processo se respalde em fatores quantitativos, tais como a exigência das peças gráficas necessárias à devida compreensão do projeto e do seu desenvolvimento. Muitas vezes, parte do critério da avaliação se apoia na verificação dessas peças gráficas. Todavia, acreditar que a qualidade do projeto pode ser aferida a partir de uma resposta meramente quantitativa é um engano.

É recorrente a frustração do estudante que apresenta todos os elementos exigidos e mesmo assim recebe uma avaliação abaixo de suas expectativas. Isso ocorre devido ao equívoco de se medir ou avaliar com instrumentos quantitativos o resultado de um exercício intelectual traduzido em uma forma. Tais elementos quantitativos são 
fundamentais e necessários à comunicação e posterior avaliação do projeto, mas não são suficientes.

Há um ponto cego na constante tentativa de sistematizar o aprendizado acerca de uma habilidade que se desenvolve a partir de um conhecimento que, apesar de operar sobre uma base concreta, é consequência de uma reflexão particular, impalpável. 0 freio moral herdado do moderno elimina da forma qualquer indício que revele uma evitável licença autoral, falsamente compreendida como indesejável sujeição à arquitetura como aparência, como imagem. Nesse sentido, enfrentar a arquitetura como linguagem e encontrar mecanismos de discussão em ateliê para a sua devida compreensão é um dos urgentes desafios do ensino de projeto de arquitetura.

Com este editorial mais autoral, alternativo à formalidade de resenhar sumariamente todos os artigos, cumpro meu período como Editor-Chefe da Revista Pós. Agradeço o suporte e a interlocução de Lina Rosa, Paola Santos, José Tadeu de Azevedo Maia e, especialmente, da Profa. Maria Lucia Caira Gitahy, e desejo um bom trabalho ao Prof. Leandro Medrano, novo Editor-Chefe da Revista Pós, que certamente desempenhará esta função com absoluta competência.

Boa Leitura

Rodrigo Queiroz

Editor-Chefe

roqueiro@usp.br 